\title{
ELDRIDGE MOHAMMADOU
}

\author{
15 January 1934-18 February 2004
}

Eldridge Mohammadou's body was returned from Nigeria to Cameroon-for a funeral on 29 April 2004 which took place more than two months after his death in Maiduguri. Protective of his privacy to the last, Eldridge had refused medical treatment until he was admitted to the university's teaching hospital. Diagnosed with heart failure, he died only two days later. Friends, family, colleagues and, apparently, even medical staff remained unaware of the severity of his condition to the end. Slipping away undemonstratively in a foreign academy may have been the end he preferred.

Despite his many friendships and collegial relations, Eldridge's reserve makes it impossible to write confidently about the facts of his life, and so this tribute has to be taken only to reflect what one friend was allowed to know about him, and much of that only after his death.

Eldridge's career began in governmental circles, but he went on to make a unique contribution to Cameroonian history both through his own work and by his nurturing others' projects. According to his curriculum vitae, before he was thirty Eldridge had served as Chief of Cabinet to the Vice-President of the Republic of Cameroon (1962-3), before moving to spend a decade at the Federal Linguistic and Cultural Centre in the Cameroonian capital of Yaoundé. His next appointment was as Head of the Research Department in the Cultural Division of the Ministry of Education and Culture, during which time his CV also has him studying for a 1973 certificate at the Ecole Pratiques des Hautes Etudes of the Sorbonne in Paris, his only tertiary qualification. In 1975, he moved on quickly to become Head of Division I (History, Languages, Anthropology) at the National Scientific and Technical Corporation, and then Co-ordinator of Museum Research of the National Secretariat for Scientific Technical Research.

At forty-six this scholarly and administrative trajectory launched him into the role of Chef de Station of the Institut des Sciences Humaines in Garoua with a mandate covering the North of Cameroon. This was the capacity in which many overseas researchers, including myself, came to know him. In Garoua he held sway over a compound and case de passage, drivers and vehicles, offices and secretaries, and even a proposed museum collection. Eldridge was in his element but, in 1991, political considerations, brought to a head by spending cuts associated with structural adjustment, put paid to Eldridge's cherished Institute, on which he moved across the border to Nigeria remaining a Visiting Professor of History in the Centre for Trans-Saharan Studies at the University of Maiduguri for the rest of his life. From Nigeria, Eldridge visited Cameroon frequently and played an important role 
in the Norwegian-funded Anthropos project, led by Lisbet Holtedahl, which built research facilities in Ngaoundere.

From the moment of his first publication in the early 1960s, Eldridge's writing hardly abated. In the couple of years I knew him in Cameroon, his post-office schedule always involved a single beer (Beaufort not '33', for Cameroonians to whom such things matter) and back at his desk to write. I doubt the habit changed later. His earliest works were about either Fulfulde language (including collaboration in the threevolumed Lexique Fulfulde comparé) or Fulbe oral traditions, both stories and historical recollections. Many of these publications were in series of relatively limited diffusion; however the mid-1970s saw the first fruits of his collaboration with the Institute of Languages and Cultures of Africa and Asia (ILCAA) in Tokyo. Nine volumes of Eldridge's writings were to appear in the ILCAA series 'African Languages and Ethnography', some of them new syntheses of his previously published work, including studies of the oral traditions of most of the Fulbe lamidates of the Adamawa Emirate that Eldridge came to know intimately from his unceasing travels. If his 1980 account Garoua: tradition historique d'un cité peul du Nord-Cameroun (with Ahmadou Bassoro, CNRS, Paris) stands out, it may be because of his particular familiarity with and affection for this city.

Another of the early ILCAA volumes had been a catalogue of the German archives in Cameroon, and Eldridge's commitment to the translation of German sources-making them available to readers in Cameroon-was as unswerving as his desire to preserve oral traditions in Fulfulde. Translations into French of Leo Frobenius's ethnological writings on Cameroon, as well as Hans Dominik's memoir of Cameroonian conquest, were published in Germany.

During the 1980s Eldridge's interests moved increasingly towards the precursors of Fulbe history in Adamawa (or Fombina) in a concerted effort to reconstruct the societies that had existed before the jihads of the nineteenth century. Initially his research concentrated on reconstructing hypothesised phases of the Kororofa kingdoms. His ambition was to emphasise the continuities between the emirate of Fombina and the empire that preceded it. Subsequently he became fascinated by largescale movements of people out of Fombina which he envisaged to have changed the political regimes of a swathe of west-central Africa. It is fair to say that the further his scholarship strayed from Fulfulde language and Fulbe history, the more controversial his historical reconstructions became. Eldridge was well aware of my own reservations about his reconstruction of Chamba history as part of his hypothesis of 'Baare' migrations. This is not to deny that migrations occurred, but Eldridge inclined to finding them pervasively on the basis of over-interpreted evidence. Eldridge continued patiently to try to persuade me of the error of my views.

Eldridge Mohammadou was intensely private about his personal life, and he divulged little of his history to many who thought they knew him 
long and well. ${ }^{1}$ The son of an English father and Fulbe mother, he had been born Maurice Eldridge, and accompanied his father to Central Africa. For secondary schooling, he was sent to Strasbourg in Alsace, completing his baccalauréat in 1954, hence his command of German and French, as well as Spanish, all honed during long bicycling holidays across Europe. Eldridge recounted that the close relation between his father and mother had not survived his father's return to England, where he married. ${ }^{2}$ Eldridge himself recalled being made to feel unwelcome by all but one aunt when he visited from France. He was to adopt the name given by his mother as his family name, continuing to be addressed by his father's surname. Many years later he would return to England while working with Lisbet Holtedahl on the well-received documentary 'The Sultan's Burden' for the television series 'Under the Sun'. The multi-ethnic composition of London's Camden Town on a Saturday afternoon, to which I took him on the only occasion I saw him outside Cameroon, amused and may even have relieved him of some of the memory of his previous visit to his father's country. Norway enlivened his interest in his 'Viking ancestors' and some time later I was asked to send books and articles on Viking history, and to venture down to Sheerness on the Isle of Sheppey, in Kent, to see whether there were local histories of the Eldridges. So far as I know, Eldridge's diffidence on such matters was never overcome sufficiently to ring any of those who shared his surname in the local telephone directory or to contact the local historical society as he had proposed. A letter in June 1997 found him definitely refusing an advertisement in the Sheerness papers that 'could disturb some of the possibly related Eldridges'. Another letter in 2000, largely concerned with hypotheses about Baare migrations, found him 'commissioning [someone] to deepen research through the internet'. Had he tried the 1901 census on-line, he would have discovered a John Eldridge of Sheerness whose son, also John Eldridge, seems about the right age to have been father to Eldridge's own father. Is this evidence for at least four generations of Sheerness Eldridges culminating in Eldridge himself? Perhaps. I have not checked but I am sorry not to be able to send him the hypothesis.

Eldridge Mohammadou was separated from his wife with whom he had twin girls, and had several other children by customary marriages. His son Abdoulaye Abdoulkarim Eldridge transferred Eldridge's substantial collection of research materials to Garoua with a view to establishing an archive accessible to international scholars (perhaps in Ngaoundere). As Nicholas David notes in his memoir, this is the very least that should be owed the legacy of a remarkable scholar and unforgettable personality.

RICHARD FARDON

\footnotetext{
${ }^{1}$ An obituary by Eldridge's friend of many years, Christian Seignobos, which appeared in Méga-Tchad (2004 [1/2]: 9-19) as this issue of Africa was in proof, clarifies aspects of Eldridge's life that were obscure to me.

${ }^{2}$ Seignobos's account differs entirely on this point and derives from a time closer to the events.
} 
Nicholas David writes: I first met Eldridge in 1967 when he was sent by Père Mveng (or more probably volunteered) to accompany me on a tour of Cameroon designed to enable me to select a site for archaeological work. This took us to Wum, Foumban, Tibati, Galim where some 'Niam-Niam' of the Benue valley had found refuge from the Fulbe, Ngaoundere, Rey Bouba and Garoua, in the vicinity of which I found the deep mound sites I was looking for to provide a chronology (see David 1968). ${ }^{3}$ Eldridge was a superb guide and interpreter (Pidgin and Fulfulde), teaching me how to interact with everyone we met from peasants to préfets, what food one could safely buy at the roadside, and what else to trust. I was impressed that the Laamiido of Rey Bouba, after a few formal minutes addressing us from behind a cloth screen, revealed himself and, dispensing with his naked-to-the-waist interpreter, engaged Eldridge in lively historical discussion.

From Garoua we went out on survey and it was Eldridge who advised me to visit Bé and present myself to its wise and generous chief, Laamiido Hamman Sali, my host in later years. That summer we dug a test excavation at Nassarao, closer to Garoua, but after a few days Eldridge left me (without warning) to my own devices and went off to work on history. Annoyed at first, I found I could cope and remained grateful for the enforced lesson in self-reliance.

We returned to Yaoundé via the eastern route with an excursion to the pastoral Mbororo Fulbe hamlet of Yarmbang, in the Mbéré drainage and close to the frontier with the Central African Republic. Eldridge, always in search of authenticity and identity, had fallen for a young woman there. I lent him money, punctiliously repaid when we returned to Yaoundé, to enable him to make the customary payments. He later married but his bride had difficulty adapting to life in Yaoundé and the marriage was soon ended.

Before I left Cameroon Eldridge was kind enough to tape all the exercises in Taylor's Fulani grammar, which I later purchased together with the dictionary. ${ }^{4}$ By the time I returned a year later, I had attempted unsuccessfully to teach Fulfulde to my student Frank Bartell, but in the process got a good grounding in it myself. Eldridge had initiated me into fieldwork in Cameroon and also into the Fulbe way-laawol pulaaku - so much so that when, over a decade later, I began to work with Mandara montagnards, I had at first great difficulty in reorienting my sympathies.

Eldridge and I saw little of each other between 1968 and 1971 and it was not until I returned to Cameroon in 1984 to direct the Mandara (Ethno-)Archaeological Project that we were again in regular contact. He was by this time chief of the Garoua station of the Institut des Sciences Humaines and greatly facilitated the administrative and

\footnotetext{
${ }^{3}$ David, N. 1968. 'Archaeological reconnaissance in Cameroon', Expedition 10 (3): 22-31.

${ }^{4}$ Taylor, F. W. 1932. A Fulani-English Dictionary. Oxford: Clarendon Press. Taylor, F. W. 1953. A Grammar of the Adamawa dialect of the Fulani Language (Fulfulde). 2nd edn. Oxford: Clarendon Press.
} 
logistic aspects of both our work, and Richard Fardon's who was there at the same time. On one occasion when Judy Sterner and I had come alone and had not yet obtained the requisite permissions from Yaoundé, Eldridge supplied us with ordres de mission on his own initiative-thus saving me several days in the capital. He also organised showings of mine and Yves Le Bléis's video Dokwaza: le dernier maître de fer africain in Maroua and Mokolo, and of a draft of Demeures des esprits: pots et personnes dans le Nord du Cameroun in Garoua. ${ }^{5}$ Those evenings-in Mokolo I marched from a party at our house to the community hall at the head of Dokwaza and his kin dancing and singing to drums and Mafa harp - are among the most memorable and rewarding of my career.

In 1991 the brutal demolition of the Garoua ISH station-he told me that police and soldiers either stole the collections that researchers had been building up over the years or tossed them out to fill potholes in the access roads-led Eldridge to transhume to Maiduguri, although he was able to retain and develop a pied-à-terre, intended as a retirement home, in Ngaoundere. A year later Judy Sterner and I began our research at Sukur, not far away to the south but in Adamawa rather than Borno State. So we refound each other in different circumstances. Eldridge, engaged in some of the most intensive writing of his career, was happy to talk with us about our work but ignored repeated invitations to visit Sukur, a pity since he had accepted some pretty silly ideas about its supposed imperialist past.

Throughout my engagement with Cameroon, Eldridge has been a valued guide and resource. Not that I accept his writings as gospel. Far from it, they are flawed and difficult to evaluate, not least because it is rarely clear upon what precise grounds and with what authority a historical proposition is stated. His uncritical acceptance, for example, of Fulbe legends of migration from Mali or of pre-colonial kingdoms in north-east Nigeria, is to be deplored. Nonetheless his access to and ability to extract information from texts and informants in the various Fulbe lamidates and other chiefdoms of Cameroon was, and will remain, unequalled. Whether working among the Fulbe of the Benue valley, the Mandara montagnards affected by the razzias of Hamman Yaji of Madagali, or last summer in Gudur shortly after having received news of his untimely death, it is to Eldridge that one first turns for the history of the past 200 years.

He was unique, a Cameroonian in search of himself who would set out for weeks and months at the wheel of a Mini Moke armed with nothing more than a notebook, a tape recorder, and less than the minimum in the way of cash and supplies. His legacy, thanks especially to his Japanese colleagues at ILCAA, is enormous though it must be

\footnotetext{
${ }^{5}$ David, N. 1990. Vessels of the spirits: pots and people in North Cameroon. Video recording (50 mins). Calgary: Department of Communications Media, University of Calgary.

David, N., and Y. Le Bléis. 1988. Dokwaza: last of the African iron masters. Video recording (50 mins). Calgary: University of Calgary, Department of Communications Media.
} 
mined and refined rather than uncritically accepted. One can only hope that his archives will be preserved and, one day, deconstructed by a historian, hopefully Cameroonian and as dedicated as himself. It will be a disgrace if no institution in Cameroon or France offers a scholarship or fellowship in his memory.

\section{ELDRIDGE MOHAMMADOU: BIBLIOGRAPHY}

Based on a curriculum vitae of Eldridge Mohammadou (hereafter E.M.), including a list of books (last entry 1991), kindly made available from the University of Maiduguri by Gisela Seidensticker-Brikay, with additions by Catherine Baroin (Mega Tchad network), Nicholas David and Richard Fardon. The CV mentions more than fifty articles in French and English in various journals, reviews, and newspapers since 1958, of which we have located only a small proportion.

Books

1965. L'Histoire de Tibati, chefferie foulbé du Cameroun. Yaoundé: Abbia \& Clé. $72 \mathrm{pp}, 1$ map.

1965. (and Henriette Mayssal, eds). Contes et poèmes foulbé de la Bénoué (Nord-Cameroun). Yaoundé: Clé. 84 pp.

1969. Les Peuls du Niger central et oriental: groupes ethniques et dialectiques. Camelang: Yaoundé, No. 2.

1969. (transcribed and edited). Récits peuls du Macina, Kounari et Torodi.

Collected and translated by Gilbert Vieillard de l'IFAN, Dakar. Niamey:

Centre Régional de Documentation pour la Tradition Orale. $253 \mathrm{pp}$.

1970. Lexique Fulfulde comparé. Volume 1 (A-D). Yaoundé: Centre Fédéral Linguistique et Culturel. 324 pp.

1970. Les Traditions historiques des Peuls de l'Adamawa. 1 L'Hisotire des Peuls Feroobe du Diamaré: Maroua et Petté. Niamey: Centre Regional de Documentation pour la Tradition Orale. $482 \mathrm{pp}$.

1971. Traditions d'origine des peuples du centre et de l'ouest du Cameroun (Mboum, Tikar, Bamoun, Bamenda, Banso, Bamileke, Voute). Yaoundé: Centre Fédéral Linguistique et Culturel, Ministère de l'Education, de la Culture et de la Formation Professionelle.

1971. Lexique Fulfulde comparé. Volume 2 (F-K). Yaoundé: Centre Fédéral Linguistique et Culturel. 258 pp.

1971. (with A. Sow, P.-F. Lacroix and D.W. Arnott). Dictionnaire élémentaire Fulfulde-Français-English. Niamey: Centre Régional de Documentation pour la Tradition Orale. 166 pp.

1971. Lisez et écrivez le fulfulde. Yaoundé: Direction des Affaires culturelles. $123 \mathrm{pp}$.

1972. Lexique Fulfulde comparé. Volume 3 (L-S). Yaoundé: Centre Fédéral Linguistique et Culturel. 294 pp.

1975. Le Royaume du Wandala ou Mandara au XIXe siècle. Paris: ORSTOM/ISH. 302 pp.

1976. L'Histoire des Peuls Férôbé du Diamaré, Maroua et Pétté. African Languages and Ethnography III. Yaoundé: ONAREST; Tokyo: ILCAA (Institute for the Study of Languages and Cultures of Asia and Africa). viii +409 pp. 
1978. Fulbe Hooseere. Les Royaumes foulbé du plateau de l'Adamaoua au XIXe siècle (Tibati, Tignère, Banyo, Ngaoundéré). African Languages and Ethnography VIII. Tokyo: ILCAA. 439 pp.

1978. Catalogue des Archives coloniales allemandes du Cameroun. African Languages and Ethnography XII. Tokyo: ILCAA. 282 pp.

1979. Tradition transmitted by Alhadji Hamadjoda Abdoullaye and edited by E.M. Les Yillaga de la Bénoué: Ray ou Rey-Bouba. Traditions historiques des Foulbé de l'Adamâwa 2. Paris: CNRS; Garoua: Musée dynamique du Nord-Cameroun. 348 pp. +26 pp, maps and illustrations.

1980. and Modibbo A. Bassoro. Garoua, tradition historique d'une cité peule du Nord-Cameroun. CNRS: Paris. 197 pp. +9 pp., maps.

1982. Le Royaume du Wandala ou Mandara au XIXe siècle. African Languages and Ethnography XIV. Tokyo: ILCAA. 333 pp.

1982. Peuples et états du Fombina et de l'Adamawa (Nord-Cameroun). Études de Kurt Strümpell et von Briesen traduites de l'allemand par E.M. Collection 'Archives Allemandes du Cameroun', no 1. Centre de Recherches et d'Etudes Anthropologiques (Département d'Histoire). Yaoundé: DGRST/ISH.

1983. Idriss Aloma, ou l'apogée du Kanem-Bornou. Libreville: Edition Lion; Dakar: Nouvelles éditions africaines (Collection 'Grandes figures africaines'). $125 \mathrm{pp}$.

1983. Peuples et royaumes du Foumbina, traditions historiques de la HauteBenoue (Nord-Cameroun). African Languages and Ethnography XVIII. Tokyo: ILCAA. 307 pp.

1983. Le Peuplement de la Haute-Benoue. 1 Les Habitants de la zone centrale. Garoua: ONAREST/CNRS. 83 pp.

1986. Traditions d'origine des peuples du Centre et de l'Ouest du Cameroun. African Languages and Ethnography XX. Tokyo: ILCAA. 207 pp.

1987. Peuples et sociétés traditionnelles du Nord-Cameroun. Etude de Leo Frobenius. Trans. from the German and introduced by E.M. Stuttgart: Steiner Verlag. $175 \mathrm{pp}$.

1988. Les Lamidats du Diamaré et du Mayo-Louti au XIXe siècle (NordCameroun). African Languages and Ethnography XXII. Tokyo: ILCAA. $324 \mathrm{pp}$.

1988. Les Lamidats des montagnes Mandara. Kyoto: s.n.

1990. Traditions historiques des peuples du Cameroun central. 1 Mbèrè et Mboum, Tikar. African Languages and Ethnography XXIII. Tokyo: ILCAA. $414 \mathrm{pp}$.

1991. Traditions historiques des peuples au Cameroun central. 2 Vouté, Ni-zoo, Kondja. African Languages and Ethnography XxIV. Tokyo: ILCAA. 302 pp. 1999. Trans. from the German and introduction. Siegfried Passarge Adamawa. Rapport du Comité Allemand par le Cameroun dans les années 1893/94. Paris: Karthala.

2002. Trans. from the German and introduction. Fritz Bauer L'Expédition allemande Niger-Bénoué-Lac Tchad (1902-1903). Paris: Karthala. 186 pp. +2 maps.

Articles

1963. 'Introduction à la littérature peule du Nord-Cameroun', Abbia 3: 66-76. 1963. 'Pour servir à l'histoire du Cameroun: la chronique de Bouba Njidda Rey', Abbia 4: 17-55.

1964. 'L'histoire des lamidats foulbé de Tchamba et Tibati', Abbia 6: 15-158. 1965. 'Contes foulbé de la Bénoué', Abbia 9-10: 11-46.

1967. 'Pour une histoire du Cameroun central: les traditions des Vouté ou "Baboute",, Abbia 16: 15-127. 
1969. 'Yeerwa: poème épique des Peuls Yillaga de l'Adamawa', Camelang 1: 73-111.

1971. and M. Abbo. 'Un nouveau manuscrit arabe sur l'histoire du Mandara', Revue camerounaise d'histoire 1: 130-173.

1974. 'De la Bénoué à Bamenda: la chevauchée fantastique des Bali-Tchamba', Cameroun-Dimanche 13-4: 6-7.

1975. 'Kalfu ou l'émirat peul de Baguirmi et les Toorobbe de Sokkoto', Afrika Zamani [Yaoundé] 4: 67-114.

1981. 'L'implantation des Peuls dans l'Adamawa (approche chronologique)', in Claude Tardits (ed.) Contribution de la recherche ethnologique à l'histoire des civilisations $d u$ Cameroun, vol. 1, pp. 229-247. Paris: CNRS (Centre national de la recherche scientifique).

1986. 'Envahisseur du Nord et Grassfields camerounais aux XVIIIème: le cas du Bamoun', Sudan-Sahel Studies II: 237-273.

1989. 'Islam et urbanisation dans le Soudan central au XIXème siècle: la cité de Maroua (Nord-Cameroun)', Proceedings of International Conference on Urbanism in Islam. Vol. 4, pp. 118-154. Research Project 'Urbanism in Islam' and The Middle Eastern Culture Center in Tokyo, Japan.

1992. 'Le soulèvement mahdiste de Goni Waday dans la Haute-Benoue (juillet 1907)', Senri ethnological studies 31: 423-464.

1994. 'Les sources de l'exploration et de la conquête de l'Adamawa et du Bornou allemands (1893-1903): Passarge, Dominik, Bauer', Paideuma 40: 37-66.

1997. 'Kanuri imprint on Adamawa Fulbe and Fulfulde', in N. Cyffer and T. Geider (eds), Advances in Kanuri Scholarship, pp. 257-311. Köln: Köppe.

1999. 'De St. Croix Fulfulde-English dictionary and recent Fulani lexicography', Borno Museum Society Newsletter 38-39: 114-123.

1999. 'Le poney conquérant des savanes du Cameroun central (c.1750-1850)', in C. Baroin and J. Boutrais (eds) L'Homme et l'animal dans le bassin du lac Tchad. Actes du colloque du Réseau Méga-Tchad, Orléans, 15-17 octobre 1997, pp. 81-106. Paris: IRD (Institut de recherche pour le développement).

1999. 'The Fulbe of eastern Niger: ethnic groups and dialects', Borno Museum Society Nerwsletter 40-41: 30-58.

1999. 'Fulani Lexicography (continued)', Borno Museum Society Newsletter 40-41: 88-90.

1999. 'Nouvelles perspectives de recherche sur l'histoire du Cameroun central au tournant du XVIIIe siècle (c.1750-1850): l'invasion Baare-Tchamba', Ngaoundéré-Anthropos 4: 53-100.

2001. 'Chronique royale versus histoire: le facteur Baare et le Bamoum au XIXème siècle (Cameroun)', in D. Ibriszimow, R. Leger, and U. Seibert (eds), Von Ägypten zum Tschadsee.Eine linguistische Reise durch Afrika (Festschrift für Herrmann Fungraithmayr zum 65. Geburtstag), pp. 273-287. Würzburg: Deutsche Morgenländische Gesellschaft, Ergon Verlag.

2002. 'History, climatology, and linguistics: Jarawan Bantu expansion from the Upper Benue Valley, c.1750'. Paper presented at a conference on 'Environmental and Cultural Dynamics in the West African Savanna', Maiduguri, March 2002. < http://www.informatik.unifrankfurt.de $/ \sim$ sfb $268 /$ maiduguri.htm $>$. 